\title{
Recent Ferroalloy Studies at Istanbul Technical University
}

\section{Onuralp Yucel ${ }^{1}$, Mehmet Bugdayci², and Ahmet Turan²}

${ }^{1}$ Metallurgical and Materials Engineering Department, Faculty of Chemical and Metallurgical Engineering, Istanbul Technical University, 34469, Maslak, Istanbul, Turkey

${ }^{2}$ Chemical and Process Engineering Department, Faculty of Engineering, Yalova University, 77200, Yalova, Turkey

\section{Abstract}

The present report is the summary of the experimental studies on the production of ferroalloys and iron-based alloys, which have been conducted in the laboratories of Macro to Nano Research Team (MtNT, Yücel's Group) at Istanbul Technical University (ITU, Turkey) - Metallurgical and Materials Engineering Department in the last decade. Ferromolybdenum, ferrochromium, ferronickel, and iron-based alloys with alloying elements ( $\mathrm{Mo}, \mathrm{Ni}, \mathrm{Cr}$, etc.) were produced through different reduction processes

Corresponding Author:

Onuralp Yucel

yucel@itu.edu.tr

Received: 5 February 2019

Accepted: 6 March 2019

Published: 17 March 2019

Publishing services provided by

Knowledge E

(c) Onuralp Yucel et al. This article is distributed under the terms of the Creative Commons Attribution License, which permits unrestricted use and redistribution provided that the original author and source are credited.

Selection and Peer-review under the responsibility of the NIOKR-2018 Conference Committee. (metallothermic and carbothermic) starting from different reactant materials such as mill scale, hematite, magnetite, $\mathrm{NiO}, \mathrm{Cr}_{2} \mathrm{O}_{3}$, chromic acid, and $\mathrm{MoO}_{3}$. The effects of different stoichiometric amounts of reactants and reductant powders were investigated for the production of unalloyed Fe. While, different amounts of metal oxide ratios and their effects on metal recoveries, compositions, and microstructure of final alloys were studied during Fe-based alloys production, raw materials and produced alloys and slags were characterized by using chemical analysis methods (AAS, ICP), X-ray diffraction spectrometry (XRD), X-ray fluorescence spectrometry (XRF), and scanning electron microscopy (SEM/EDS) techniques.

Keywords: iron-based alloys, carbothermic reduction, metallothermic reduction, iTU

\section{Introduction}

Ferroalloys are critical materials for a sustainable metal industry and for economy. Macro to Nano Research Team (MtNT, Yücel's Group) is a research group which mainly deals with the optimization of processes in extractive metallurgy, valorization and recycling of metallurgical wastes and the synthesis of advanced ceramics. The research group has conducted projects which were supported by private companies across the world, by governmental funds and by the EU funds with local and European partner research 
Production of ferroalloys and iron-based alloys have been important subjects to carry out projects for the research group over the last decades. Those are "Production of ferronickel from domestic lateritic ores", "Production of molybdenum containing iron based alloys via self-propagating high temperature synthesis", "Optimization of parameters of ferromolybdenum production via metallothermic reduction process", "Production of nickel pig iron from domestic lateritic ore", "Production of molybdenum, nickel, chromium containing iron based alloys via metallothermic process" and "Low carbon ferrochromium production from Eti Krom concentrate via SHS process" (Figure 1). In the present study, the results of the projects in question are summarized respectively [1-8].

\section{Experimental Studies and Results}

\subsection{Production of ferronickel from domestic lateritic ores}

Ferronickel production from domestic ores containing 1.58\% Ni, 24.76\% Fe and 34.35\% $\mathrm{SiO}_{2}$ from Manisa-Caldağ region and optimization of production parameters were studied. Grinding and calcination processes (at $1100{ }^{\circ} \mathrm{C}$ ) were carried out to increase the nickel content of ore and for ore preparation, then ferronickel was obtained from calcined ore and reductant mixture through carbothermic reduction. Laboratory scale rotary kiln and graphite resistance tube furnace were used in calcination and reduction studies. Metals and slags, were obtained from reduction processes, were characterized by using electron probe microanalysis (EPMA) and chemical analysis techniques. Metallic iron, as well as total iron, nickel and cobalt contents were measured and, metallization amounts were calculated.

In the experimental studies, ferronickel was obtained by the reduction of domestic lateritic nickel ore in graphite crucibles. Reduction parameters were optimized by applying temperatures from $1450{ }^{\circ} \mathrm{C}$ to $1550{ }^{\circ} \mathrm{C}$ and durations up to 60 minutes. In the second experimental set, the effect of alumina-based crucible was examined with process durations up to 60 minutes by using domestic metallurgical coke (containing 87 wt.\% fixed C) at the temperatures of $1500{ }^{\circ} \mathrm{C}$ and $1600{ }^{\circ} \mathrm{C}$. For the experiments in graphite crucibles, a maximum nickel recovery of ratio of $90.98 \%$ was reached whereas the maximum ratio was $85.67 \%$ for the experiments by using alumina crucibles [1]. 

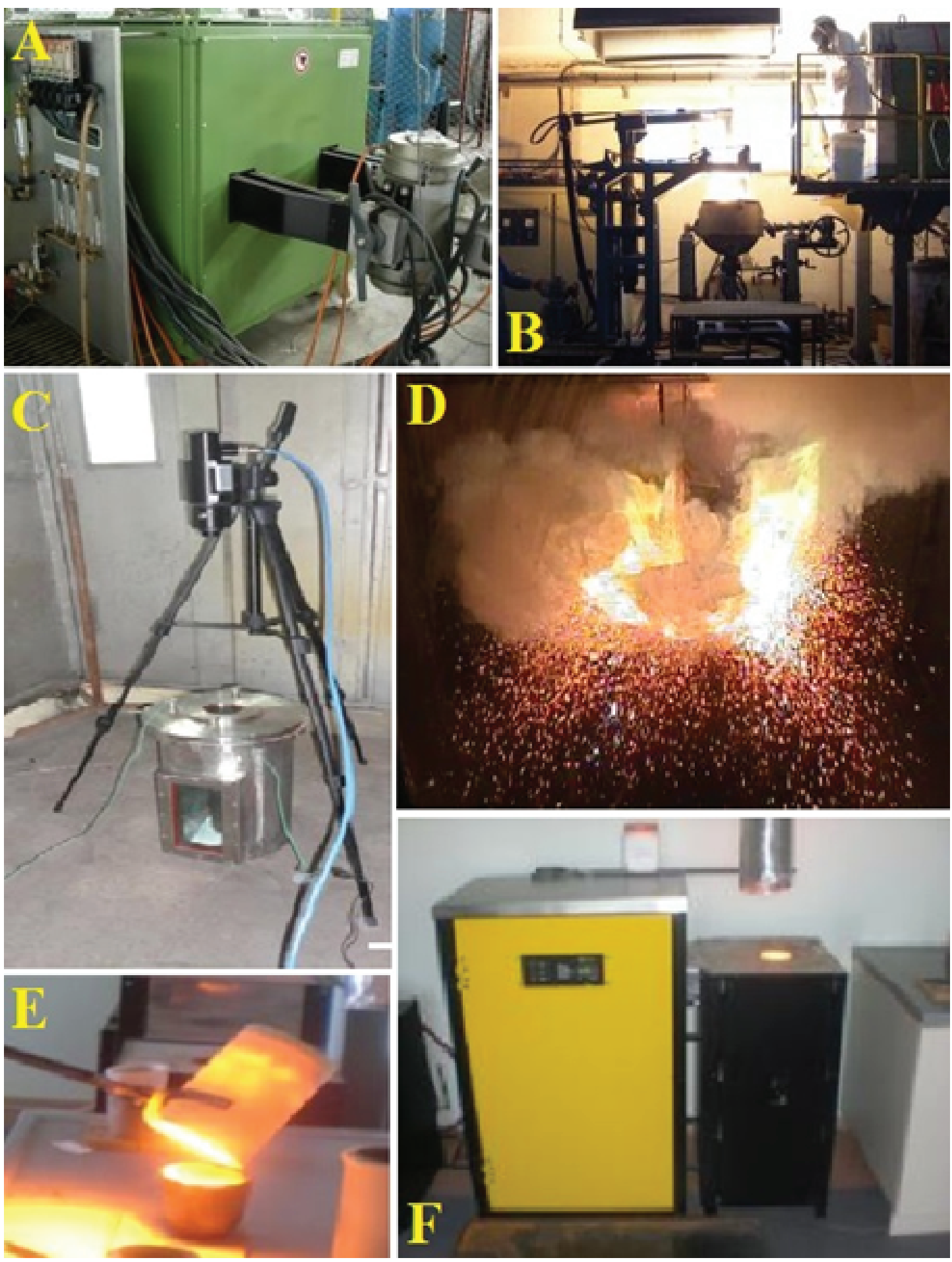

Figure 1: Selected photos from ferroalloy and iron-based alloy production studies (A, B: Carbothermic ferronickel production; C, D: Metallothermic reduction process, E, F: Nickel pig iron production). 


\subsection{Production of molybdenum-containing iron-based alloys via self-propagating high-temperature synthesis}

This study was conducted through a self-propagating high temperature synthesis (SHS) process to produce $\mathrm{Fe}-\mathrm{Ni}-\mathrm{Cr}-\mathrm{Mo}$ alloys from reactant mixture of $\mathrm{Fe}_{2} \mathrm{O}_{3}, \mathrm{NiO}, \mathrm{Cr}_{2} \mathrm{O}_{3}, \mathrm{MoO}_{3}$ with Al-Si reductant powders. The advanced thermochemical simulations of the reactions were investigated in detail including different ratios of initial mixtures, appropriate flux, heat sinker or increaser additions as well as different initial temperatures in order to reduce the number of experiments. The phase compositions of the SHS products were characterized by using chemical analysis, XRD and EDS techniques. Initial molar compositions of each mixture were calculated and, mixtures were prepared by mixing for 15 minutes in turbula mixer. After drying, mixtures were charged into copper crucibles. Tungsten wire was placed on top of the copper crucible and the reaction started by passing current through the wire. After initiation, the highly exothermic reaction becomes selfsustaining and propagates throughout the SHS mixture, yielding the desired product. After that, SHS products were taken out mechanically, crushed and grinded.

Effects of changing Al content, stoichiometrically from $100 \%$ to $120 \%$, was investigated. Total yields of metals and $\mathrm{Fe}, \mathrm{Cr}, \mathrm{Ni}$ and Mo yields of alloys reached the highest values, although the $\mathrm{Cr}$ content increased considerably but did not reach the exact target compound value. The highest total metal recovery of all experimental groups was $87.57 \%$ with the addition of $115 \%$ stoichiometric Al to the initial mixture. However, according to the chemical analysis of obtained products, the amount of $\mathrm{Al}$ in the metal is very high. That did not cause for the formation of desired result in our target compound values. Theoretically, it is necessary to prevent from the contamination of metal by aluminum which was used as reductant [2].

\subsection{Optimization of parameters of ferromolybdenum production via metallothermic reduction process}

In this study, production conditions of ferromolybdenum alloys by metallothermic reduction process were investigated. The formation of FeMo was conducted by using technical grade $\mathrm{MoO}_{3}$, granulated $\mathrm{Fe}_{2} \mathrm{O}_{3}$, steel scrap, aluminum, ferrosilicon, $\mathrm{CaO}$ and $\mathrm{CaF}_{2}$ powders. Effects of crucible volume, addition of $\mathrm{Ca}$ based fluxes, stoichiometric ratio of $\mathrm{Al}, \mathrm{FeSi}$ and addition of steel scrap for metallothermic experiments were investigated, respectively. Ferromolybdenum alloys and slag phases were obtained from experiments. 
All experiments were conducted by using $\mathrm{MoO}_{3}$ of $300 \mathrm{~g}$. Different ratios of $\mathrm{CaO}$, $\mathrm{CaF}_{2}$, Al (stoichiometrically from $90 \%$ to $110 \%$ ), steel scraps and FeSi were added to see their effects. Mo recovery efficiencies were found to be between $35.5 \%$ and $69.4 \%[3,4]$.

\subsection{Production of Nickel Pig Iron (NPI) from domestic lateritic ores}

Experiments were performed in an induction furnace with graphite crucibles. Lateritic ores were employed as raw material to produce nickel pig iron from East Anatolian Region. Effects of reductant ratio, process duration and flux addition $(\mathrm{CaO})$ were investigated. Lateritic ores and coke were dried in a drying furnace at $105^{\circ} \mathrm{C}$ for 2 hours. 100 g ore and metallurgical coke (from $5 \mathrm{~g}$ to $35 \mathrm{~g}$ ) were mixed and charged into an induction furnace which is commercially designed for F9 and F10 graphite based crucibles. These mixtures were held for 25 minutes in the furnace at temperature range of 1600-1650 ${ }^{\circ} \mathrm{C}$. It was observed that charged mixtures began to melt after 10 minutes (1350-1400 ${ }^{\circ} \mathrm{C}$ ) and reached the maximum temperature after 15 minutes. Metallic and slag phases were obtained after smelting. Slags were discarded and grinded. Magnetic-metallic and non-magnetic parts of the slags were separated by using magnetic separation process. Magnetic parts were added to the metallic phase to re-melt.

The highest metal recoveries were achieved for the experiments conducted with the addition of $30 \%$ of metallurgical coke as $91.99 \% \mathrm{Ni}, 93.87 \% \mathrm{Co}$ and $69.40 \% \mathrm{Cr}$ at the processes time of 35 minutes. Metal concentrations in the alloy were $3.13 \%$ for $\mathrm{Ni}, 0.17 \%$ for $\mathrm{Co}$ and $5.07 \%$ for $\mathrm{Cr}[5-7]$.

\subsection{Production of molybdenum, nickel, chromium-containing iron-based alloys via metallothermic process}

It was aimed to produce Fe-based alloys via SHS metallurgy which is attractive process technique regarding fast and low-cost production ability of cast alloys by using high metallic iron content by reducing continuous casting mill scale. Mill scale is a layer of iron oxide which forms on ferrous materials cooling after being processed in hot rolling or continuous casting plants. Mill scale contains iron (II) and iron (III) oxides, which result in a $70 \%$ total iron content in oxide form.

A mixture of mill scale, $\mathrm{NiO}, \mathrm{Cr}_{2} \mathrm{O}_{3}, \mathrm{MoO}_{3}$ and $\mathrm{Al}$ powders were used in order to produce metallic $\mathrm{Fe}, \mathrm{Fe}-\mathrm{Ni}$, $\mathrm{Fe}-\mathrm{Ni}-\mathrm{Cr}$, and $\mathrm{Fe}-\mathrm{Ni}-\mathrm{Cr}-\mathrm{Mo}$ alloys. The metal oxide powders have over $96 \%$ purity and $150 \mu \mathrm{m}$ average grain sizes. Thermochemical simulations 
of the reactions were investigated in detail including different ratios of initial mixtures, appropriate flux, heat sinker or increaser additions as well as different initial temperatures in order to reduce the number of experiments.

$\mathrm{NiO}$ addition into green mixtures decreased the total metal recovery. On the other hand, $\mathrm{Cr}_{2} \mathrm{O}_{3}$ addition into green mixtures decreased the scattered ratio due to lower exothermic feature of $\mathrm{Cr}_{2} \mathrm{O}_{3}$ reduction [8].

\subsection{Low carbon ferrochromium production from Eti Krom concentrate via SHS process}

Chromium and its alloys are produced with high energy consumption and $\mathrm{CO}_{2}$ emission. Low carbon-containing ferrochromium is commonly used in industrial applications. In this study, low carbon ferrochromium alloy were produced via metallothermic SHS process starting from Eti Krom chromite concentrate without using any external energy.

Eti Krom concentrate consisted of $47.16 \% \mathrm{Cr}_{2} \mathrm{O}_{3} .98 \%$ pure $\mathrm{Al}$ powder was used as a reductant and minimum $99.7 \% \mathrm{CrO}_{3}$-containing chromic acid was added into the charge. Grinded $\mathrm{CrO}_{3}$ and chromite concentrate were dried at $105^{\circ} \mathrm{C}$ in a drying oven for $30 \mathrm{~min}$ utes. Ratios of reactant powders were calculated by using FactSage 6.2 thermochemical simulation software database. After reduction experiments, the highest recovery ratio, as $66.46 \%$, was obtained with the addition of $110 \%$ stoichiometric $\mathrm{Al}$ and $65 \%$ to $35 \%$ concentrate $/ \mathrm{CrO}_{3}$ ratio [8].

\section{Conclusions}

Several ferroalloys and iron-based alloys (such as FeNi, FeCr, FeMo, and nickel pig iron) were successfully produced via carbothermic and metallothermic reduction methods at ITU Metallurgical and Materials Engineering Department laboratories. The details of conducted experimental studies can be found in the references of this report.

\section{References}

[1] Çolakoğlu C., Derin B., Yücel O. (2009), A Study on Nickel Containing Iron Alloy Production from West Anatolian Region Lateritic Ores, TMS Annual Meeting, Feb. 15-19, 2009, San Francisco, USA.

[2] Kirgöz D., Alkan M., Yücel O. (2013), Production of Molybdenum Containing Iron Based Alloys via Metallothermic Processes, 2013 TMS Annual Meeting, 3-7 Mart, 
San Antonio, USA.

[3] Güven G., Alkan M., Derin B., Yücel O. (2011), A Study on Ferromolybdenum Production by Metallothermic Reduction Process, 2011 TMS Annual Meeting, February 27 March 3, San Diego, California, USA.

[4] Alkan M., Güven G., Derin B., Yücel O. (2015), Optimization of Parameters of Ferromolybdenum Production via Metallothermic Reduction Process. SHS XIII. 12-15 October 2015, Antalya, Turkey.

[5] Yıldırım H., Turan A., Yücel O. (2012), Nickel Pig Iron (NPI) Production from Domestic Lateritic Nickel Ores Using Induction Furnace. IISS 2012, International Iron \& Steel Symposium, 02-04 April 2012, Karabuk, Turkey.

[6] Yildirim H., Morcali H., Turan A., Yucel O. (2013), Nickel Pig Iron Production from Lateritic Nickel Ores. INFACON XIII, $13^{\text {th }}$ International Ferro Alloys Congress, 9-12 Haziran 2013, Almaty, Kazakhstan.

[7] Yucel O., Turan A., Yildirim H. (2012), Investigation of Pyrometallurgical Nickel Pig Iron (NPI) Production Process from Lateritic Nickel Ores, 2012 TMS Annual Meeting, 11-15 March, 2012, Orlando, Florida, USA.

[8] Gungor M. N., Benzesik K., Bugdayci M., Yucel O. (2015), Production of Molybdenum, Nickel, Chromium Containing Iron Based Alloys via Metallothermic Process, XIV. INFACON 2015, 1-5 June 2015, Kyiv, Ukraine. 